\title{
Being taken seriously - shaping the pathways taken by Welsh female entrepreneurs
}

\author{
Christine Atkinson
}

Faculty of Business and Society, University of South Wales, Trefforest, Pontypridd. CF37

1DL, Telephone: 01443483678 email: christine.atkinson@southwales.ac.uk

Celia Netana

Faculty of Business and Society, University of South Wales, Trefforest, Pontypridd. CF37 1DL, Telephone: 01443482585 email: celia.netana@southwales.ac.uk

David Pickernell (Corresponding Author)

Portsmouth Business School, University of Portsmouth, Richmond Building, Portland Street

Portsmouth PO1 3DE Telephone: 02392844184email: david.pickernell@port.ac.uk,

\section{Zoe Dann}

Portsmouth Business School, University of Portsmouth, Richmond Building, Portland Street Portsmouth PO1 3DE, Telephone: 02392 844827, Email: zoe.dann@port.ac.uk

Acknowledgement: This work was supported by European Social Fund (ESF) funding in conjunction with the Welsh Assembly under Project Identification number 2015-1-UK01KA203-013847

Keywords : gender; inequality; Wales; entrepreneurial capital; women; credibility 


\title{
Being taken seriously - shaping the pathways taken by Welsh female entrepreneurs
}

\begin{abstract}
Despite rapid growth in female entrepreneurship globally, the gender gap in self-employment remains and women's full contribution to the economy via self-employment continues to be unrealised. This paper explores pathways taken by women in Wales at start up and whilst running their own businesses. Female self-employment is a useful focus given current political interest and policy focus on SMEs revitalising the Welsh economy. Using a phenomenological approach employing narrative techniques and business life histories, a grounded account is provided of entrepreneurial practice from perceptions of the female entrepreneur herself. In their sense making, female entrepreneurs convey how lack of credibility (in terms of "not being taken seriously") and consequently the pursuit of attaining an often elusive level of credibility, strongly shapes business decisions and entrepreneurial experiences and occurs regardless of levels of educational achievement, previous work experience or industry sector, adding a layer of complexity to business decisions and strategies.
\end{abstract}

Keywords : gender; inequality; Wales; entrepreneurial capital; women; credibility, being taken seriously 


\section{Being taken seriously - shaping the pathways taken by Welsh female entrepreneurs}

\section{Introduction}

The focus of this paper is to understand how the perceived need by female entrepreneurs to "be taken seriously" shapes pathways towards and during self-employment by women in Wales. The lived experiences of female entrepreneurs across the globe are markedly different and cannot be captured by statistics alone (Brush et al., 2009, Fielden and Davidson, 2010). Fielden and Davidson (2010) argue that the motivations of business owners, and in particular, women business owners, are complex and should be understood within the context of the country they live in and the socio-cultural factors they experience.

Wales has the lowest Gross Value Added (GVA) per Capita ranking compared to other areas of the UK (Jones, 2015) and lower than UK average rates among female self-employed (Hart, Levie, Bonner and Drews, 2014). A focus on Female entrepreneurship is germane given the current political situation and policy focus on small business as a way to revitalise the Welsh economy. Examining available statistics on the industrial structure of female selfemployment in Wales, more rural areas tend to be more reliant upon sectors such as agriculture and activities related to tourism (e.g. hotels and restaurants). These are both sectors in which Welsh female self-employment is more highly concentrated than other parts of the United Kingdom (Regional Trends, 2017).

A deeper and more grounded understanding of constraints and opportunities of entrepreneurial motivation and action from the perspective of female entrepreneurs is key to encouraging more women into business and supporting those already in business in Wales. As a small nation within the UK with a strong cultural identity and history of heavy industry (coal mining, steel), Wales has a strong work/gender segregation history reflecting the work available during that time yet there is little documented and therefore known about Welsh women's historic economic contribution (John, 2011). Whilst women in the UK make up just 
under half the workforce, they only represent $32 \%$ of all self-employed (Office for National Statistics, 2013) and most of those are in relatively low growth, low value added service sectors (Marlow and McAdam, 2012). Although statistics such as these clearly identify the gendered gap in entrepreneurship, causes of the gap have not been adequately explored and suitably analysed and the potential of female entrepreneurs continues to be unrealised.

Wales has experienced a difficult transition to a post-industrial or knowledge-based economy (Cooke and Clifton, 2005) and has received European Union and Government funding to support areas of economic development including entrepreneurship. Whilst economic independence, is a goal of the Roadmap for equality between men and women (EC, COM (2010) 491 final) achieving this, requires inclusion of women in labour markets and selfemployment (Parken, 2010). In addition to the economic shift, Wales has undergone political changes in the last two decades with the introduction of devolved governance. Devolved nations in the UK have distinct economic strengths and weaknesses and are developing policies to tackle those issues specific to the area.

The opportunities and challenges in the current climate and economic history give a distinct backdrop for women in self-employment in Wales compared to other regions in the UK. For example, more women in Wales use self-employment as a primary source of income than those in other areas of the UK (Regional Trends, 2017), however, according to HMRC (2016) Wales has lower than UK average self-employed income. Wales' distinct patterns of employment show a higher than UK average in part-time work, with women in the majority of those earning less than $£ 7$ per hour and comprising $79 \%$ of all part-time jobs in Wales. With employed work and a high proportion of public sector sectors jobs at risk of budget cuts and redundancies self-employment could offer a way to improve prospects. These stark differences suggest differing motivations for self-employment in Wales and the need for further exploration. 
Despite Wales' occupational structure having a higher than UK average selfemployment concentration of manager and senior official roles, a range of obstacles continue to impede pathways to female self-employment typically through occupational segregation and low involvement in self-employment beyond those areas traditionally dominated by women such as clerical, cleaning, cashier, carer, and catering, the "5Cs" (Carter and Shaw, 2006, p43). This is in part related to the failure of the market to exploit women's increased education performance, itself detrimental to Wales's wealth creation strategies such as Economic Renewal (WAG 2010). In Wales, in common with most of the rest of the world, the number of women moving into self-employment is increasing, but there are still fewer self-employed women than men. Women constitute just under half the workforce but only represent $32 \%$ of all self-employed (ONS, 2016). Welsh government policy reiterates the need to encourage selfemployment and start-up rates, with self-employment as a route out of economic inactivity being identified as a priority.

Using a qualitative, narrative approach, this paper draws on challenges and embedded notions of women in self-employment and female entrepreneurs. Research tends to comprise of what women are perceived to be lacking compared to their male counterparts. These "female underperformance" approaches inadequately capture the complexities of the everyday life of the female entrepreneur (Zolin, Stuetzer and Watson, 2013) and perpetuate the assumption of many women that entrepreneurship is not a place where they belong or that business simply isn't "for me". However, this assumption is challenged in the liberal feminist literature and given the same conditions, male and female entrepreneurs can achieve the same levels of success (McAdam, 2013, Fapohunda, 2013). However, terminology and standardized characteristics of female entrepreneurs in extant literature are often different to how women business owners perceive themselves (Welch, Welch and Hewerdine, 2008) which has led them to question the relevancy of research in this area. In taking a grounded approach, the study this 
paper draws on helps bridge that gap and provide insight into female entrepreneurship as actually enacted.

\section{Literature: The need for gendered perspectives Questioning the female underperformance thesis}

According to recent surveys (BIS 2015a, BIS 2015b) only around 20\% of SMEs in the UK are woman led and men continue to be more likely to start-up their own business. While the gender gap in entrepreneurship is clear, a criticism in the literature of research into female entrepreneurship is the failure to look outside of traditional male norms to fully explore the dimensions of women's experiences as business owners, particularly in their own words. The focus on measuring performance via profit and growth metrics contributes to the "underperformance" perception of female entrepreneurs (Zolin et al., 2013), focussing on what women are purported not to do rather than gaining understanding of what they are actually doing.

\section{Pluralistic views and contextual richness}

Feminist debate, however, provides pluralist views of motivations to start a business and questions these masculinised normative measures (Galloway et al., 2015). There are questions in the literature on the benefit of the search for one overarching concept or theory relating to entrepreneurship at the cost of failing to capture the diversity and complexity of its agents and communities (Welter, 2011), marginalising women as being outside the norm of what is considered to be enterprising activity. There is a lack of reflection of the real world of enterprise where the majority of small businesses are not growth oriented (Ahl, 2006, Galloway et al, 2015), research consequently missing the complex historical context and accumulation of everyday obligations contributing to the entrepreneurial actions of business owners. A more 
grounded approach and less simplistic view, taking into account gendered perspectives is therefore considered a suitable mechanism.

\section{Female entrepreneurship as performance}

Following Butler (1990) and subsequent proponents, Galloway, Kapasi and Sang (2015) propose a 'performative' approach to female entrepreneurship in order to offer a different perspective, considering multiple motivations of entrepreneurial activity. They recognise that, whereas modern theory on leadership considers the value of both feminine and masculine characteristics, entrepreneurship theory remains masculinised. Rather than focusing on performance outcomes this approach explores activity undertaken within gender role norms allowing a deeper exploration of motivation - not to start and end the conversation with earning or not earning but why business owners carry on through the challenges and difficult initial stages and continue with their businesses.

Understanding the ebb and flow of entrepreneurship as a process (Moroz and Hindle, 2012) constructed from everyday decisions and strategies allows for a more grounded understanding of entrepreneurial activity. Motivations for entrepreneurship or becoming selfemployed are no longer purely reported as being dichotomous opportunity or necessity. For women in business, motivations are complex, differing between industries (Handy, Ranade and Kassam, 2007), geographical locations and cultures (Fielden and Davidson, 2010). The gendered aspect of female entrepreneurship is also explored at different levels of society affecting the female entrepreneur's life on micro, meso and macro levels (Brush et al., 2009) and the influence of the multiplicity of life experiences comprising their total entrepreneurial capital (Junquera, 2011).

\section{Gender and the Social construction of enterprise}


A gendered perspective adds a greater depth of understanding of female entrepreneurial practice than, for example, literature discussing non-growth small firms (tending to be more female than male led) which are often termed as "lifestyle" businesses, differentiating them (Bruni, Gherardi, and Poggio, 2004) from "proper business" and providing little to improve the credibility of female entrepreneurship or our understanding of their entrepreneurial practice.

\section{Belonging and authenticity}

Belongingness and authenticity to entrepreneurship as a true-to-self (feminine) entrepreneur impinge on entrepreneurial action. Lewis (2013) highlights the challenge of being authentic, keeping true your (feminine) self, whilst needing to perform at so-called "professional" (masculinised) working practices, Ahl (2006) highlighting that within liberal feminism there is reasoning that without the discriminations women face that they would behave and achieve as do men . Studies such as Stead (2017) therefore explore how women employ specific identities in order to perform "belonging" and explores the ways women behave within a gendered entrepreneurial environment. Stead (2017) identifies typologies of female entrepreneurial behaviour which both adhere to and challenge gender roles in order to be accepted and be taken seriously as part of the entrepreneurial community.

\section{Organisational legitimacy and entrepreneurial capital}

The accumulation of different types of entrepreneurial capital as a means of gaining entrepreneurial and organisational legitimacy is discussed in the literature. For example, gendered structural constraints such as disparity of income and limits on performance of women evident in employment are also evident in self-employment (Loscocco and Bird, 2012) as are the influence of the multiplicity of life experiences comprising their total entrepreneurial capital (Junquera, 2011). Loscocco and Bird (2012) also highlight that gendered structural 
constraints exist within the workforce and "closer to home", impacting on the decision to start a business at micro, meso and macro levels. Brush et al. (2009) go further to argue that the basic 3M framework (Money, Market, Management) needs to be extended by the other 2Ms (Macro/Meso environment and "Motherhood"), in order to provide a more useful framework to guide understanding gender as a social construct and how individuals act within that construct. Brush, de Bruin and Welter (2009) therefore propose the "5 M" framework, as a more holistic way in which to understand women's entrepreneurship, the 5 sets of factors as follows:-

M1. Market (Access to markets, which can also be seen as Opportunity-entrepreneurship related)

M2. Money (Financial Capital)

M3. Management (Human and organisational capital, which can also be seen to be related to social capital and networks)

M4. Motherhood (A metaphor representing family and household contexts for female entrepreneurs)

M5. Macro/Meso environment (The Macro environment including national policies, strategies, but also cultural and economic influences, the meso environment reflecting more regional support policy services and initiatives)

Of particular relevance to this study is the accumulation of skills, qualifications and experience (human capital) to the individual's total capital to a level perceived to be acceptable. This is of particular significance from a gendered perspective and raises questions around enterprise as meritocratic, particularly for women. Therefore literature around human capital (mainly education and previous employment experiences) and how these foundation phases can be said to contribute to the overall entrepreneurial capital of the individual to start and run their own business from a gendered perspective is also of importance.

For example, the influence of educational experiences on the pathway to selfemployment is one such complex motivational factor, creating opportunities for some but 
constraints for others, impacting not just the development of the business but also the selfefficacy and confidence levels of the entrepreneurial individual. Global Entrepreneurship Monitor (GEM) consistently report of the positive association between educational attainment and likelihood to start a business, with the GEM Women's Report (Kelley et al., 2014) suggesting that female entrepreneurs are more highly educated than male entrepreneurs particularly in innovation driven industry sectors. However, education still presents significant gendered aspects with more male than female graduates reported to be likely to obtain higher level and higher paid jobs after graduation regardless of level of academic attainment achieved (ONS, 2013).

Less, however, is known on the influence of education on pathways to self-employment, particularly from a gendered perspective. What has been presented in the literature is not a universal reflection on female entrepreneurship and is an area worth continued attention in order to understand how female entrepreneurs use education to navigate their business lives. Bennett and Dann (2000), for example, recognise the changing dynamics in the area of education and motivation to becoming self-employed. They found that education and motivation amongst their sample of Australian female entrepreneurs differed from findings in previous studies, with more female entrepreneurs coming from a business specific educational background than previously reported.

\section{Career Progression and Occupational segregation}

Previous employment is a key determinant in the choice of industry for those entering selfemployment. The literature is consistent in the view that the majority of entrepreneurs set up business in an industries where they have previous work experience. Occupational segregation, therefore presents an obvious constraint for female entrepreneurs who have been previously employed before deciding to set up their own business in terms of leadership experience, access 
to networks and of particular interest to this paper, a track record, providing a level of credibility (McAdam, 2013). Issues around frustration at lack of progression in the workplace and the search for a better work-life balance are also common themes in discussions around women's motivation to enter self-employment (Buttner and Moore, 1997).

\section{Gendered perspectives - gaining greater insight into career pathways}

Gendered perspectives are challenging what has become "known" about female business ownership although studies on the impact of previous employment and pathways to selfemployment remain scant. Previous research on movement from employment to selfemployment have also been criticised due to the lack of empirical evidence and tend to articulate the male experience (Mallon and Cohen, 2001). There is a continued need for deeper understanding of the many interrelated triggers, situational and temporal factors, ethics and values of the individual which motivate a woman to leave organisational employment to start their own business (Mallon and Cohen, 2001). Sweeping terminology such as "necessity" has also been of limited help in the field of female entrepreneurship, over-reducing the component parts of the decision to undertake a new pathway such as self-employment. Superficial terminology has not captured the complex gendered issues across all aspects of women's lives and how they align with each other and has offered limited benefit to our understanding.

Hughes (2003) identifies duality of push and pull factors in her sample where the primary motivators might be described as "push" factors but sub-motivators more "pull” based. Recognising the cumulative nature of decision making and how entrepreneurs draw on past experience, it remains important to understand how the human capital of the individual guides and restrains their pathways. Ranson (2003) compares career paths of engineering graduates in Canada. For the men in this group autonomy and control was found to mean leading the business and being in charge, but for the women in that group autonomy tended to mean greater 
flexibility to do other things in their lives. This highlights the importance of qualitative investigation in order to better understand the context of meaning amongst the sample and the complexity of female entrepreneurship (Henry, Foss and Ahl, 2013). Therefore the study this paper draws on has taken a qualitative, gender sensitive, narrative approach and provides examples of "what" female entrepreneurs do when faced with situations where they perceive their gender to be an issue.

\section{Method}

The study on which this paper draws comprises a sample of 15 women owners or majority business owners across Wales. An exploratory inductive phenomenological approach was used to capture the depth of data required to allow adequate insight into this complex subject area. Research participants were recruited using convenience and purposive methods, in order to generate a sample that covered a range of experiences of female entrepreneurship in terms of longevity, sector and location. In order to undertake the study we generated a full complement of fifteen first round interviews, generating full and summary business life histories. Fourteen second round interviews were also carried out to generate a longitudinal aspect to the method as allow us to ask interviewees for reflections on their activities since the first round of interviews. One person was unavailable for the second round interviews due to a family bereavement.

For full analysis of these issues within the context of the research questions that formed the basis of the analysis, verbatim interview transcripts were uploaded onto Nvivo analysis aiding software (version 10) for coding and thematic analysis. This analysis built on the identified emerging themes across all 15 cases. Analysis also included comparing cases across business profile data collected as part of the interview process. Interview transcripts were then developed into narrative "business life histories" also incorporating the researchers' notes and 
reflections and elements of the business profile questionnaire completed by each participant capturing demographic details about their business (for example, age and type of business, turnover, type of premise). This combination of data allows observation of perspectives of each business owner, giving a more complete view of often complexity situations (Thomas, 2011).

Summaries of the narratives capturing the business life histories of fifteen female participants in English (and also translated into Welsh) were sent to each participant for comment before being finalised. Direct quotes from the interviews have been interwoven into each case to include "the voice" of the business owner themselves. This grounded approach, using cases, is considered most appropriate in order to capture the multiplicity and interaction or "weaving" of contexts drawn from past experiences within the entrepreneurial reality (Welter, 2011). Narrative life histories are an effective medium to convey the complexity of lived experiences and offering insight from a gendered perspective to areas such as motivation and notions of success which have had previous discussion in the literature but less frequently including the female perspective (Mallon and Cohen, 2001). A narrative approach also assists by giving us an understanding of more than just the beginning and end of the journey and allowing us access to the context of decision making from the participant's perception and could help in dispelling some of the embedded myths around entrepreneurial journeys common in western literature (Smith and Neergard, 2015). A life history, or rather a "business life history" type analysis comprising the case studies themselves is being applied and key themes identified aided by Nvivo software (version 10).

Life story techniques offer particular benefit to the field of female entrepreneurship in counteracting previous research which has tended to focus on what is considered to be lacking by female entrepreneurs in comparison to male counterparts. Life story techniques have been used in the field of Life Sciences and are particularly powerful in giving voice to those less frequently heard (Sosulski, Buchanan and Donnell, 2010). Collecting participant's own 
interpretations of their experiences and social circumstances in which their story has unfolded in their own "voice" also allows greater understanding of what female entrepreneurs actually do rather than where they are perceived to underperform. Narrative and language are useful tools to expose individual experiences of more intangible aspects such as wider social inhibitors and hegemonic power structures specific to the individual's own social context (Roets and Goedgeluck, 1999 and Sosulski et al. 2010).

The findings illustrate how women perceive themselves and their businesses in the environment around them, what motivates them to start and keep going in business and ultimately, how they navigate obstacles and opportunities and choose the pathways they've taken based on their life and business experiences in a way not traditionally used in entrepreneurship literature but of particular relevance to the field of female entrepreneurship. This gender sensitive approach to analysis has been used to illustrate representations of female entrepreneurs in the context of that individual (McAdam, 2013, Fielden and Davidson, 2010 and Kariv, 2013). A narrative approach therefore helps us build an iterative course of events and decisions made from the perspective of the female entrepreneur assisting in building the context surrounding the individual. This is important in the field of entrepreneurship where much of the extant research has focussed on outcomes rather than the pathway taken to produce those outcomes (Kariv, 2013). Hughes and Jennings (2012) further support the importance of studies exploring gender as it influences behaviour, quoting Ahl's call for studies to treat gender not as "something that is" but "something that is done".

More specifically, it is argued that gender is something which should not be used as a variable but more as a "lens", a context which needs more focus in future research (McAdam, 2013). The qualitative research study conducted aims to counteract more traditional quantitative research which focuses on women's "underperformance" in self-employment (by 
using gender as a simple dependent variable) by means of a more gender sensitive, qualitative approach allowing for better analysis of the contexts in which female entrepreneurship takes place. The study therefore uses cases to capture the business life histories of female small business owners across Wales, to capture the influence and impact of previous life experiences on their decision to start their own business and to continue to run their own business.

\section{Results}

The methodology used in our study has enabled us to explore themes already existing in the literature but within the context of the individual female business owner. Three key themes were identified across the total sample of fifteen: Motivation, Success, and Being Taken Seriously. Motivations to start a business tend not to be a simple choice of necessity or opportunity but a response to a mixture of needs and aspirations (better earnings, autonomy, creativity, lack of respect, lifestyle, caring responsibilities) through different stages of their personal and business lives. In addition, while success is a factor which we are more used to seeing condensed to a single figure (e.g. employees, sales or profit) or percentage (e.g. growth rate), success occurred in our sample in the plural, within multiple aspects, relating to the way each woman has uniquely crafted her life. While motivation and success can be seen as the impetuses to start the business and continue in business, needing to be taken seriously both guides and constrains the business owner towards particular paths, certain decisions, and specific strategies on an ongoing basis.

Being taken seriously was a key theme our respondents related to credibility, mostly manifesting itself in the perception by the female entrepreneur of how credible other people perceive her to be. Where there was a lack of being taken seriously, it led to reported feelings of self-doubt by the female business owners in terms of their achievements and capabilities. Most frequently amongst our sample this is expressed by perception of not being good enough 
or that they don't belong. Also reported were instances of actions and decisions undertaken in order to attain the perceived required level of credibility in order to be taken seriously in the entrepreneurship community. What is interesting in our sample and particularly noticeable in the business life histories format is the persistence of this issue albeit on a spectrum of severity across cases. Whilst it might be expected at start up or when changing roles or industries, the perceived need by the female entrepreneur to be taken seriously was present at all levels of experience and business stages, all levels of educational and career achievement and across different industry sectors (although more prevalent in some than others). The perceived need to be taken seriously has a major impact on the motivation to start a business, to keep the business running and was a key component of the different forms of success aspired to and enjoyed by our sample of female business owners adding another level of complexity to making business decisions. The business life histories show the impact of this issue and how the results of not being taken seriously can have a lasting negative impact on the female business owner despite the experience, education level and financial success.

The narrative form then allows full cases to explore the impact of constraints and opportunities reported by the female business owner at micro, meso and macro levels from their own perspective. Our participants reported pathways to self-employment that are varied and reflect decisions made and opportunities taken within the context of the individual's circumstances and also the constraints and opportunities within the industry sector they work in.

\section{Overview of Jessica's story}

Jessica lives in North Wales and works nationally. She and her husband jointly own a training and consultancy company (a Limited company with three employees) and works an average 
50 hours a week. The consultancy has been trading for eight years with an annual turnover between $£ 100,001-£ 200,000$.

In her formative years, Jessica experienced strongly defined gendered roles, with her mother giving up her career as a midwife when she got married. Jessica believes this influenced her and her sisters to seek out careers in well paid "non-traditional" industries. She did well at school. Her father wanted her to study maths and science, however, she rebelled and studied her passion, Psychology, instead. After graduating, Jessica worked overseas, in marketing and engineering as well as a fast track leadership programme in the Police. However, she experienced negative gendered attitudes at an organisational level as well as from individual male managers throughout these experiences where she was predominantly in the minority as a woman: "If you could prove you could do the job then you would be accepted. If men make mistakes they're human, and women because they're women. So you couldn't afford to make a mistake".

After a medical condition forced her to leave the Police, Jessica undertook a teaching qualification and took up hourly paid work at a tutoring agency. She enjoyed the freedom of working in this way, meeting new people and the control she had over her workload, allowing her to simultaneously run her therapy practice. One contract led to a permanent role in a Management Consultancy where Jessica came into contact with freelance consultants and liked their way of working. On meeting her husband, Jessica decided to move to North Wales. As there weren't as many management consultancy opportunities in that location, Jessica found that freelancing allowed her to work nationally for big corporations, run her psychology therapy practice and also live where she wanted to: "So again it was getting the balance, the flexibility to live where I wanted to live and also do other things. So that was my reason for going self-employed then." 
Later on Jessica closed her therapy practice and formed a Limited company which won a contract for delivering training at an engineering company. After 18 months, Jessica's company was asked to deliver more training but this time to the next management level up. Jessica was asked if her male colleague could run the session as a woman would not be taken seriously at that level. She felt she was faced with the business choice of tackling this issue with the Managing Director or keeping their business. Jessica spoke to the Managing Director on this matter. Whilst he was receptive to her in person and listened to her points, Jessica did not receive any further contracts from that company.

You don't have the credibility as a woman in engineering... I obviously hadn't built the credibility enough to think that I could stand in front of the middle managers. And what that has done, and I hate to say this, is I doubt myself now, whereas I didn't doubt myself before.

The issue of credibility has therefore been a persistent theme in Jessica's employed work history but was especially crucial in setting up and running her small business. Jessica's negative experiences of the male dominated industry sectors of engineering and the Police whilst in employment, motivated her to search for and eventually create a less constrained working environment by founding her own consultancy business, only to come up against gendered obstacles on the part of a client, the impact of which is now for her to take a step back from delivery and focus more on strategy, focusing on a different industry sector to deliver a new training programme.

\section{Overview of Alison's story}

Alison, based in rural West Wales, currently has two businesses (Limited companies) within the Education sector and has been self-employed for over 17 years. She left school with two O-levels in art and design and cookery, not knowing her career options and feeling let down by her educational experience. Her dyslexia was undiagnosed and she was constrained by others' perception that she was academically incapable. Alison had hoped to take IT, a newly 
available subject in her school at that time, but as a girl was only given the option of typing: "I didn't really know what I wanted to do ...I hated school and I hated the fact that I was being singled out as not able...because I was able..."

Lack of encouragement at school meant she did not stay for A-levels. She left with little idea of her strengths her only thought of a potential career, a chocolatier, having no suitable course at her local college. She eventually chose a course by "teenage logic", picking the shortest queue available, which was childcare and become a qualified nanny (a " $5 \mathrm{C}$ " occupation), working and travelling with families: “...looking back it's really quite depressing that we weren't encouraged to look at different options..."

At 19 Alison became pregnant. The agency she worked for stopped further nanny roles as her pregnancy progressed but offered her some help if she wanted to set up her own nanny agency. This appealed to Alison as she could leave London and move back and work from home with the baby right next to her. Despite not having previous business experience or business training, save legal requirements remembered from her college course, Alison took them up on their offer: “...I didn't know how to run a business...nobody had ever explained to me what a business really was..." Alison's family helped supplement her financially as she struggled with her business for almost a year eventually realising it was not going to work. Alison then found a job as a nursing home manager but still wished to pursue self-employment despite her initial lack of success: "I hankered...really hankered after going to work for myself..."

Whilst employed and with her manager's support, Alison undertook management, business and IT courses at a local college and applied her learning to the nursing home. She enjoyed this far more than her learning experience at school sparking an ambition to become a teacher and take a teacher training qualification. Alison also took part-time jobs in as many 
different types of business so she could learn how they worked. Despite then developing her business as a success, Alison found that she was not recognised as "the boss" by those outside her organisation: “...somebody was... wanting to negotiate and talk about a big project... and they said no we'd rather talk to the boss and he said that IS the boss..."

Even now she ponders on whether this was because she looks young for her age, was not wearing the right clothing or does not carry herself as someone who successfully runs their own business. The work involved in having a large (21 employee) business affected Alison's work/life balance and health leading her to decide that big was not necessarily her business ambition. She was working more hours than ever before yet her income did not match: “...I thought that was success...the bigger you grow the business the more turnover you have...but going back on my own I have more money than I did when I had 21 staff..."

Alison now sees her constant push to achieve bigger business, more qualifications, more awards, was a continuation of her need to prove herself to those who had thought her incapable at school. Alison decided to downscale her business so it was just her again and plans to continue to push herself and explore new avenues. She recognises that now she has the balance of interesting, lucrative work and family life and that attainment has been worth all the effort. However, despite this success, she still notices some discrepancies in terms of pay:

... it is not necessarily about the money...but there is that to it as well that I will think, hang on a minute-that guy is earning that! How come he is earning that much and I am only earning this...?

The final business life history excerpt is an example of a woman who has always worked in family run small business and again illustrates gendered issues across different industries.

\section{Overview of Jo's story}


Jo is a sole trader and professional artist in Gwynedd with an annual turnover is $£ 20,001$ $£ 30,000$ drawing upto $£ 5,000$ personal income from her business. She has extensive work experience in small family business prior to starting up on her own having worked in her mother's successful antique jewellery business for 18 years. The pace of the business was intense with extensive travel around the UK. Jo then had the chance to buy her mother's business when her mother's health failed but her husband thought it was too risky. She moved on to work for her father in the construction industry on an eight house project starting just months before she was due to give birth to her youngest child where she was involved in numerous tasks across the business from accounting, to payroll, to chasing employees who arrived late and even taking people to A\&E a few times! In stark contrast to her mother's business, this was not an enjoyable time Jo feeling that the men on the site did not like a woman "in their territory". She recalls the verbal abuse and swearing as "horrendous" and that the construction team "put her through her paces". It was only when they realised that Jo was a signatory on the pay cheques that the verbal abuse waned a little: "I did withhold payment from some of them and then they realised what was going on and stopped but had I not had the power it would have been really horrid".

Jo returned to work a month after her baby was born and found this time particularly difficult with a punishing home/childcare/work daily routine. Jo describes herself at that time as "a machine". When the project finished, she felt very low and sought medical help. However, during her recovery she discovered she had artistic talent, finding the unconstrained environment of this process therapeutic: “...I enjoyed the experience and 1. You are sitting down 2. Your mind is focussed on the [drawing] and nothing else..."

She sold her first (small) piece, just a few weeks after making it for $£ 25$. Eleven years on and her biggest items sell for $£ 1,000$. She has learnt optimum prices and products yet, despite being in a prime location in a busy town centre, has not had the desired level of sales 
so has decided to end the lease on her gallery. People tend to come in, look around, say they like it but don't buy anything: "Compliments do not pay bills unfortunately!" Jo recognises similarities between her experiences as a woman in the Construction industry and that of the Art world. Although not as verbally obvious as the Construction, Jo has felt that she does not belong in the Art world. As a self-taught artist and working in a non-traditional medium, Jo has faced negative attitudes from some of those within the industry who she feels perceive her as being "only craft" and so in an attempt to appease this criticism, decided to work in the traditional medium of oils and is having formal tuition: "To be perceived as something less than you are is very hurtful." During the second interview five months later, Jo is still taking formal tuition in oil painting but has also decided to put her art on the back burner for a while and has a new venture within the local tourist industry.

\section{Discussion}

Jessica's story is an example of someone seeking so called "non-traditional" educational subject choices and industry sectors in order to avoid the low pay, long hours trap and maximise her career and earning prospects. Of all the barriers she perceived she encountered along her pathway into and through self-employment, being taken seriously continues, however, to be a pivotal and overarching theme. Jessica's story is therefore a powerful illustration of the continuation of women's pathways to employment and self-employment in terms of the industries they work. Despite many years, of experience within an industry, relevant qualifications and proven competence, however, Jessica was perceived to still not be at the required level. The meritocratic environment Jessica has looked to create on a micro level was therefore still contending with gendered obstacles at the meso and macro societal and industry sector levels highlighted in the 5M (Brush et al, 2009) framework . 
Alison's pathway into and through self-employment also demonstrates the lasting impact not being taken seriously can have at different stages of a business woman's life and business development. Alison continues to experience limitations and impediments that she apportions to perceptions around her gender. Specifically, having started as a "necessity" entrepreneur, Alison pushed to achieve an assumed definition of success which she now recognises was more about proving to others she was capable rather than the fulfilment of her own goals and ambitions, the realisation of which ultimately leading to another change in here self-employment pathway. This supports the existing literature that identifies that female motivations are complex and differing (Fielden and Davidson, 2010), but also highlights the role of credibility within this as a dynamic, but changing motivator.

Alison's story also, however, provides insight into how such experiences in early education, in addition to employment and self-employment can both limit and motivate the individual's ambitions and options. Whilst Alison's story is an example of how a " $5 C$ " job can impact progression and ability for the individual to cope with life events in terms of options for earning, it also shows how positive experiences of education and employment can allow for the individual to be able to spot and exploit opportunities - especially relevant in the context of self-employment and conversely how a negative educational experience can have a limiting impact on the individual's feelings of self-worth and potential career options. Alison's story therefore provides examples of education being used as a ladder to progress for "necessity" entrepreneurs and also highlights the complexities and process of "push" factors to entrepreneurship. Alison's story is particularly important in terms of the role of education. For example, it could partly indicate the need for a stamp of credibility, to have the business credentials, highlighting an identified that many women lack necessary business skills due to a lack of business specific education in compulsory level education and type of previous 
employment. The reasons for this lack, however, are not simple, themselves highlighting gendered issues at those earlier stages of education.

Jo's story highlights both the resilience shown in her business journey and also the impact of different elements of Brush et al's (2009) 5M framework at different points in that journey . She has had the full spectrum of experience of working in and running a small business across three different industries. In each industry she has shown she is hard working and more than competent across a broad range of skills, but has still faced considerable obstacles, from (M1-related) lack of financial independence in relation to the first business to make the decision of whether to take up an opportunity or not, to (M5-related) being told you don't belong in the industry or feeling that what you are producing is not of high enough value to be considered credible in that industry.

The three narratives presented above clearly contribute to better understanding entrepreneurship as a process continuously reconstructed from everyday decisions and strategies, supporting the work of Moroz and Hindle, (2012), and allowing for a more grounded understanding of female entrepreneurial activity. It also supports the importance of the individual elements identified in the 5M framework (Brush et al, 2009), though with different mixtures of the $5 \mathrm{M}$ elements being apparent between the three cases and through time. More specifically, the impact of the education and learning experience was often negative at the early compulsory level, and more positive at later points through both formal and informal learning experiences.

In addition, in terms of Bennett and Dann's (2000) and Kelley et al's (2014) research, the cases suggested that one of the reasons for the strong role of post compulsory, business or profession specific education for female entrepreneurs was in terms of attempting to gain credibility. Often this was also linked to issues around occupational segregation and multiple 
sectoral activities, often related to gendered experiences. Constraints consequently imposed by a lack of relevant leadership experience, access to networks and track record to provide credibility (McAdam, 2013) were at least partially related to then seeking additional education and qualifications in areas of relevance to the businesses subsequently created. Whilst the cases also supported Buttner and Moore's (1997) work concerning the roles of frustration at lack of progression in the workplace, and the search for a better work-life balance being common themes in the women's motivations to enter self-employment, they can also be seen to have played a continuing role after self employment had been achieved, with Ranson's (2003) finding that female self-employment for reasons of autonomy in terms of greater flexibility to do other things in their lives found to be supported through the continuing entrepreneurial journey.

\section{Conclusions}

This paper adds to what is known about female entrepreneurs from the perception of the female entrepreneur herself, countering the overly simplistic comparison of male and female entrepreneurs which has tended to focus on where women are perceived to be lacking. Breaking down decision making processes and circumstances leading to specific business decisions and strategies allows a better understanding of the more intangible barriers to female entrepreneurship such as hegemonic power structures and societal factors as seen through the eyes of the woman herself. One such pervasive factor and the focus of this paper, is the pursuit of an elusive level of credibility expressed by our participants as the need to be taken seriously.

Cases such as those excerpted in this paper can be said to be more exemplary of the experiences of the majority of women business owners in Wales, counteracting the "heroic", masculinised portrait of the entrepreneur which does not resonate with many women business owners. Terminology and standardized characteristics of female entrepreneurs in extant 
literature are often different to how women business owners perceive themselves (Welch et al., 2008) which leads practitioners to question the relevancy to them of research in this area. The purpose of taking a grounded, narrative approach is to help bridge that gap and better articulate the female entrepreneur's lived experience and perceived opportunities and constraints and contribute to the ongoing discussion in the field of female entrepreneurship in areas that are relevant and beneficial to the women themselves as well as the wider economy. A more grounded articulation of how meso and macro level societal factors impact everyday decisions and strategies of the women business owner is also considered crucial in assisting with 'gender sensitising' policies, providing an evidence base for future action and providing new insights into women's experience of self-employment in Wales.

In terms of policy implications, there is a need for targeted, gender specific interventions to help women to both start-up, but also then develop their businesses. Based on the study this paper draws on, it is suggested here that interventions offering the most potential in supporting women's onward progression are related to education and training, networking and mentoring. This study also highlights a continued need for data collection of female entrepreneurs across Wales, particularly gender disaggregated data.

\section{Acknowledgement:}

This work was supported by European Social Fund (ESF) funding in conjunction with the Welsh Assembly under Project Identification number 2015-1-UK01-KA203-013847

\section{References}

Ahl, H. (2006). Why Research on Women Entrepreneurs Needs New Directions. Entrepreneurship Theory and Practice 30 (5), 595-621.

Bennett, R., \& Dann, S. (2000). The Changing Experience of Australian Female Entrepreneurs. Gender, Work and Organisation, 7 (2), 74-84.

BIS (Department for Business, Innovation and Skills). (2015a). Small Business Survey Businesses with no employees https://www.gov.uk/government/publications/smallbusiness-survey-2015-businesses-with-no-employees [Accessed May 2016] 
BIS (Department for Business, Innovation and Skills). (2015b). Small Business Survey - SME employers. Retrieved from https://www.gov.uk/government/publications/smallbusiness-survey-2015-businesses-with-employees [Accessed May 2016]

Bruni, A., Gherardi, S. \& Poggio, B. (2004). Entrepreneur-mentality, gender and the study of women entrepreneurs, Journal of Organisational Change Management, 17 (3), 256268.

Brush, C., de Bruin, A., \& Welter, F. (2009). A gender-aware framework for women's entrepreneurship. International Journal of Gender and Entrepreneurship, 1(1), 8-24.

Butler, J. (1990). Gender Trouble London: Routledge.

Buttner, E.H. \& Moore, D.P. (1997). Women's organizational exodus to entrepreneurship: selfreported motivations and correlates with success. Journal of small business management, 35(1), 34-46.

Cooke P. \& Clifton N. (2005). Visionary, precautionary and constrained 'varieties of devolution' in the economic governance of the devolved UK territories. Regional Studies, 39 (4), 437-451.

Fapohunda,T. M. (2013). Gender Differences in Human Capital and Personality Traits as Drivers of Gender Gap in Entrepreneurship: Empirical Evidence from Nigeria. British Journal of Management \& Economics, 3 (1), 40-47.

Fielden, S. L., \& Davidson, M. J. (Eds.) (2010). International Research Handbook on Successful Women Entrepreneurs. Cheltenham: Edward Elgar.

Galloway, L., Kapasi, I., \& Sang, K. (2015). Entrepreneurship, Leadership, and the Value of Feminist Approaches to Understanding Them. Journal of Small Business Management, 53 (3), 683-692.

Hart, M., Levie, J., Bonner, K. \& Drews C-C. (2014). Global Entrepreneurship Monitor: United Kingdom 2014 Monitoring Report Retrieved from http://www.gemconsortium.org/report/49102 [Accessed July 2015].

Handy, F., Ranade, B., \& Kassam, M. (2007). To profit or not to profit: Women entrepreneurs in India. Non profit Management and Leadership, 17(4), 383-401.

Henry, C., Foss, L., \& Ahl, H. (2013). Parallel Lines? A Thirty-Year Review of Methodological Approaches in Gender and Entrepreneurship Research. ISBE Institute for Small Business and Entrepreneurship, Cardiff, UK.

HMRC (2016) "Survey of Personal Incomes 2013-14" Retrieved from https://www.gov.uk/government/uploads/system/uploads/attachment_data/file/510927 /National_Statistics_T3_12_to_T3_15_Publication.pdf [Accessed June 2016].

Hughes, K. D. (2003). Pushed or Pulled? Women's Entry into Self-Employment and Small Business Ownership. Gender Work and Organization, 10 (4), 433-454.

Hughes, K.D. \& Jennings, J.E. (2012). Global women's entrepreneurship research: Diverse settings, questions and approaches. Cheltenham/Northampton, U.K.: Edward Elgar.

John, A.V. (2011). Our mothers' land : chapters in Welsh women's history, 1830-1939 Cardiff: University of Wales Press.

Jones, C. (2015). Prosperity and Place. Cardiff: Federation for Small Businesses.

Junquera, B. (2011). Where does female entrepreneurial human capital come from? A review of the literature. Innovation: Management, Policy \& Practice, 13 (3), 391-411.

Kariv, D. (2013). Female entrepreneurship and the new venture creation: An international overview. Abingdon: Routledge. 
Kelley, D., Brush, C., Greene, P., Herrington, M., Ali, A., \& Kew, P. (2014). Global Entrepreneurship Monitor Special Report: Women's Entrepreneurship. Retrieved from http://www.gemconsortium.org/report/49281 [Accessed May 2016]

Lewis, P. (2013). The Search for an Authentic Entrepreneurial Identity: Difference and Professionalism among Women Business Owners. Gender, Work and Organisation, 20 (3), 252-266.

Loscocco, K., \& Bird, S. R. (2012). Gendered Paths: Why Women Lag Behind Men in Small Business Success. Work and occupations, 39(2), 183-219.

Mallon, M. \& Cohen, M. (2001). Time for a Change? Women's Accounts of the Move from Organizational Careers to Self Employment. British Journal of Management, 12 (3), 217-230.

Marlow, S. \& McAdam, M. (2012). Analyzing the Influence of Gender Upon High-Technology Venturing Within the Context of Business Incubation. Entrepreneurship Theory and Practice, 36(4), 655-676.

McAdam, M. (2013). Female Entrepreneurship Abingdon: Routledge.

Moroz, P. \& Hindle, K. (2012). Entrepreneurship as a Process: Toward Harmonizing Multiple Perspectives. Entrepreneurship Theory and Practice, 36 (4), 781-818.

Office for National Statistics (2013). Full Report: Graduates in the UK Labour Market. Retrieved from http://www.ons.gov.uk/employmentandlabourmarket/peopleinwork/employmentande mployeetypes/articles/graduatesintheuklabourmarket/2013-11-19 [Accessed April 2016]

Office for National Statistics (2016) "UK Labour Market" Retrieved from: http://www.ons.gov.uk/employmentandlabourmarket/peoplein work/ [Accessed July 2016]

Parken, A. (2010). Gender, Knowledge Dynamics and Regional Policy In H. Halkier, J. Manniche, M., Dahlstrom, \& L. Smid-Olsen, (Eds), Knowledge Dynamics, Regional Development and Public Policy, Denmark: University of Aalborg Press, Published on behalf of the EURODITE project sponsored by the Sixth Framework Programme of the European Union (Contract no. 006187). ISBN 978-87-92305-04-6.

Ranson, G. (2003). Beyond 'Gender Differences': A Canadian Study of Women's and Men's Careers in Engineering. Gender, Work and Organisation, 10 (1), 22-41.

Regional Trends (2017). Retrieved from http://webarchive.nationalarchives.gov.uk/20160105160709/http://www.ons.gov.uk/o ns/rel/regional-trends/regional-trends/index.html.

Roets, G. \& Goedgeluck, M. (1999). Daisies on the Road: Tracing the Political Potential of Our Postmodernist, Feminist Approach to Life Story Research. Qualitative Inquiry. 22, 169-174.

Sosulski, M., Buchanan, N. \& Donnell, C. (2010). Life History and Narrative Analysis: Feminist Methodologies Contextualizing Black Women's Experiences with Severe Mental Illness. Journal of Sociology \& Social Welfare, 35(3), 29-57.

Smith, R. \& Neergaard, H. (2015). Telling business stories as fellowship-tales. International Journal of Gender and Entrepreneurship, 7 (2), 232-252.

Stead, V. (2017). Belonging and women entrepreneurs: Women's navigation of gendered assumptions in entrepreneurial practice. International Small Business Journal, 35 (1), $61-77$. 
Thomas, G. (2011). How to do your case study: A guide for students and researchers. London : Sage.

Welch, C., Welch, D., \& Hewerdine, L. (2008). Gender and export behaviour: Evidence from women owned enterprises. Journal of Business Ethics, 83 (1), 113-126.

Welsh Assembly Government (2010). Economic Renewal: A New Direction, Department for Economy and Transport, Cardiff: Welsh Assembly Government

Welter, F. (2011). Contextualizing Entrepreneurship-Conceptual Challenges and Ways Forward. Entrepreneurship Theory and Practice, 35(1), 165-184.

Zolin, R., Stuetzer, M., \& Watson, J. (2013). Challenging the Female Underperformance hypothesis. International Journal of Gender and Entrepreneurship, 5 (2), 116-129. 